$\begin{array}{ccc} & \text { ACADEMIA ROMÂNĂ } & \text { Rev. Roum. Chim., } \\ \mathbf{2 0 2 1}, \text { 66(2), 105-117 }\end{array}$

Review

\title{
STEREOCHEMISTRY - KEY ROLE IN THE REARRANGEMENTS OF DIBENZO-C8 AND -C9 DERIVATIVES
}

\author{
Anca HIRTOPEANU, ${ }^{\mathrm{a}}$ Cristina FLOREA ${ }^{\mathrm{a}}$ and Michaela Dina STANESCU ${ }^{\mathrm{b} *}$ \\ a "C. D. Nenitzescu” Center of Organic Chemistry, Roumanian Academy, 202B Spl. Independenței, 060023 Bucharest, Roumania \\ b "Aurel Vlaicu” University, Elena Dragoi str. 2-4, 310330 Arad, Roumania
}

\begin{abstract}
This paper presents the pioneering research being initiated and conducted by the late Acad. C. D. Nenitzescu and Acad. E. Cioranescu in the Department of Organic Chemistry of the University POLITEHNICA Bucharest, and the Center of Organic Chemistry of the Roumanian Academy. A review of these works seems necessary in order to emphasize the importance of the described researches in their theoretical and practical aspects. The dibenzo-cycloalkanes are compounds with interesting behavior, giving different rearranged products, difficult to obtain by other type of syntheses. The modification of the product stability given by adding a carbon atom to the side chain is also of interest, the steric factor changing radically the behavior of homologue compounds. The potential biological activity of some of these compounds is important for practical applications. The studied compounds were the subject of several $\mathrm{PhD}$ theses of the members of Acad. Cioranescu's research team. It should also be mentioned that the obtained bridged compounds are raw materials for interesting heterocyclic compounds like the tryptycene analogue prepared in collaboration with Acad. A. T. Balaban.
\end{abstract}

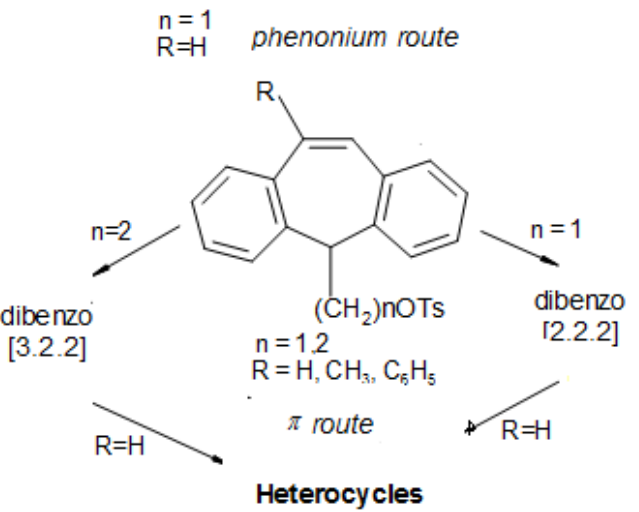

\section{INTRODUCTION}

Starting with 1960, the research group of Professor Ecaterina Cioranescu, under the leadership of Professor Costin D. Nenitzescu, investigated the chemical behavior of compounds with dibenzo cyclo- and bicyclo-alkane skeleton. The studied compounds were of interest due to their transformations, by various skeleton rearrangements leading to new compounds with possible biological activity, such as the polycyclic heterocycles compounds, synthesized together with A. T. Balaban.

In fact, the interest for such compounds was generated by the development, since 1950, of a new class of drugs, the tricyclic-antidepressants ${ }^{1}$ which have been considered "ion channel blockers". ${ }^{2}$ Many other Amitriptyline-related derivatives have been recently synthetized and used as drugs in the treatment of depression ${ }^{3}$ or as chelating agents ${ }^{4}$ (see Figure 1).

\footnotetext{
${ }^{*}$ Corresponding author: stanescu@uav.ro
} 
<smiles>[R]N(C)CCC=C1c2ccccc2CCc2ccccc21</smiles>

Amitryptiline $\left(\mathrm{R}=\mathrm{CH}_{3}\right)$ Nortryptiline $(\mathrm{R}=\mathrm{H})$<smiles>CC(CC1c2ccccc2CCc2ccccc21)CN(C)C</smiles>

Butryptiline<smiles>CNCCCC1c2ccccc2C=Cc2ccccc21</smiles>

Protryptiline<smiles>CN1CCC(=C2c3ccccc3C=Cc3ccccc32)CC1</smiles>

Cyproheptadine<smiles>CN(C)CCCN1c2ccccc2CCc2ccccc21</smiles>

Imipramine<smiles>CCON=C1c2ccccc2CCc2ccccc21</smiles>

Noxiptiline

Fig. 1 - Tricyclic-antidepressant drugs.<smiles>[X]C1Cc2ccccc2CC([Y])c2ccccc21</smiles><smiles>OCC1c2ccccc2C(CO)c2ccccc21</smiles><smiles>CCCCCCC</smiles><smiles>[X]CC1c2ccccc2C=Cc2ccccc2C1C=CC</smiles><smiles>O=C1CC2c3ccccc3C1c1ccccc12</smiles>
7

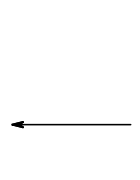<smiles>[X]C1c2ccccc2C2CC1c1ccccc12</smiles><smiles>[X]C1Cc2ccccc2C=Cc2ccccc21</smiles>

$+$<smiles>C1=Cc2ccccc2/C=C\c2ccccc21</smiles>

5

Scheme 1

A number of these compounds have a $5 H$ dibenzo[a,d]cycloheptene skeleton ${ }^{5-8}$ or a rearranged one, ${ }^{9,10}$ which makes the synthesis of similar structures of great interest. The various health problems solved by these drugs have maintained their importance till today consequently revealing the value of the research done in this area by Acad. Ecaterina Cioranescu and her coworkers. The studies were focused on obtaining new products, elucidating their structure and on the reaction mecanisms involved. The molecular kinetic studies gave information on the stability of products obtained from solvolysis or pyrolysis reactions in these series.

\section{Rearrangements of dibenzo-C8 compounds}

The beginnings of this study were devoted to the dibenzo-C8 derivatives and their transformations. The first exploration in this area started under the 
supervision of Professor Nenitzescu, and was dedicated to the transformations of the dibenzo C8 derivatives, by solvolytic reactions, in different reaction conditions. ${ }^{11-14}$ Thus, the ditosylate 1 was first transformed in 5H-dibenzo[a,d]cycloheptene derivatives 2, which are intermediates for other rearrangements. These transformations of compounds 2 occurred by the assistance of one of the phenyl rings or of the double bond of the central 7-membered ring. The first route is known as the phenonium route while the second is called the $\pi$-route. These rearrangements are presented in Scheme 1.
The structure of the compounds obtained by solvolysis, and their quantities, depend on the reaction conditions (see Table 1).

The main product obtained by the buffered formolysis of ditosylate $\mathbf{1}$ was the dibenzo $\mathrm{C} 7$ derivative $\mathbf{2}$ while the buffered acetolysis led to compound $\mathbf{4}$ with a dibenzocyclooctatriene skeleton (Scheme 1). Both products are obtained by a ring enlargement; most probably via a phenonium route. ${ }^{15}$ The following intermediates seem plausible for explaining the obtained products (see Scheme 2).

Table 1

Solvolytic transformation of tosylates $\mathbf{1}$ and $\mathbf{2}$

\begin{tabular}{|c|c|c|c|c|c|c|c|c|c|c|}
\hline \multirow[t]{2}{*}{ No } & \multirow{2}{*}{$\begin{array}{l}\text { Initial } \\
\text { compd. }\end{array}$} & \multirow{2}{*}{$\begin{array}{l}\text { Reaction conditions } \\
\text { (molar ratio: buffer/initial } \\
\text { compd.) }\end{array}$} & \multicolumn{8}{|c|}{ Products (\%) } \\
\hline & & & 2 & 3 & 4 & 5 & 6 & 7 & 8 & Lit \\
\hline 1 & 1 & $\begin{array}{l}\text { a) } \mathrm{HCOOH}+\mathrm{HCOONa} \\
(2.2 / 1) ; \text { b) } \mathrm{Na}_{2} \mathrm{CO}_{3}\end{array}$ & $85(\mathrm{X}=\mathrm{H})$ & - & - & - & - & - & - & 11,14 \\
\hline 2 & 1 & $\begin{array}{l}\text { a) } \mathrm{AcOH}+\mathrm{AcONa}(2.2 / 1) \text {; } \\
\text { b) } \mathrm{Na}_{2} \mathrm{CO}_{3}, \mathrm{KOH}\end{array}$ & - & $8(X=H)$ & $\begin{array}{c}65 \\
(\mathrm{X}=\mathrm{H})\end{array}$ & - & - & - & - & 11,14 \\
\hline 3 & $2(\mathrm{X}=\mathrm{Ts})$ & $\begin{array}{l}\text { a) } \mathrm{HCOOH} \text {; } \\
\text { b) } \mathrm{Na}_{2} \mathrm{CO}_{3}, \mathrm{KOH}\end{array}$ & $99.0(\mathrm{X}=\mathrm{H})$ & - & - & - & - & $1.0(\mathrm{X}=\mathrm{H})$ & - & 12,14 \\
\hline 4 & $2(X=T s)$ & $\begin{array}{l}\text { a) } \mathrm{AcOH} \\
\text { b) } \mathrm{Na}_{2} \mathrm{CO}_{3}, \mathrm{KOH}\end{array}$ & $81.5(\mathrm{X}=\mathrm{H})$ & - & - & 7 & - & $8.5(\mathrm{X}=\mathrm{H})$ & 3.5 & 12,14 \\
\hline 5 & $2(X=T s)$ & $\begin{array}{l}\text { a) } \mathrm{AcOH}+\mathrm{AcONa}(0.4 / 1) \\
\text { b) } \mathrm{Na}_{2} \mathrm{CO}_{3}, \mathrm{KOH}\end{array}$ & & & $\begin{array}{c}85.5 \\
(\mathrm{X}=\mathrm{H})\end{array}$ & & $\begin{array}{c}4.5_{\text {endo }} \\
+2_{\text {exo }} \\
(\mathrm{X}=\mathrm{H})\end{array}$ & & & 12,14 \\
\hline 6 & $2(X=T s)$ & $\begin{array}{l}\text { a) } \mathrm{AcOH}+\mathrm{AcONa}(0.9 / 1) \\
\text { b) } \mathrm{Na}_{2} \mathrm{CO}_{3}, \mathrm{KOH}\end{array}$ & $50(\mathrm{X}=\mathrm{H})$ & - & $45(\mathrm{X}=\mathrm{H})$ & 5 & - & - & - & 13,14 \\
\hline 7 & $2(\mathrm{X}=\mathrm{Ts})$ & $\begin{array}{l}\text { a) } \mathrm{AcOH}+\mathrm{AcONa}(1.2 / 1) \\
\text { b) } \mathrm{Na}_{2} \mathrm{CO}_{3}, \mathrm{KOH}\end{array}$ & $5(\mathrm{X}=\mathrm{H})$ & - & $95(\mathrm{X}=\mathrm{H})$ & - & - & - & - & \\
\hline 8 & $2(\mathrm{X}=\mathrm{Ts})$ & $\begin{array}{l}\text { a) Pivalic acid } \\
\text { b) } \mathrm{Na}_{2} \mathrm{CO}_{3}, \mathrm{KOH}\end{array}$ & $52(\mathrm{X}=\mathrm{H})$ & - & $19(\mathrm{X}=\mathrm{H})$ & 18 & - & - & 11 & 12,14 \\
\hline
\end{tabular}

${ }^{*} \mathrm{Ac}=\mathrm{CH}_{3} \mathrm{CO}$

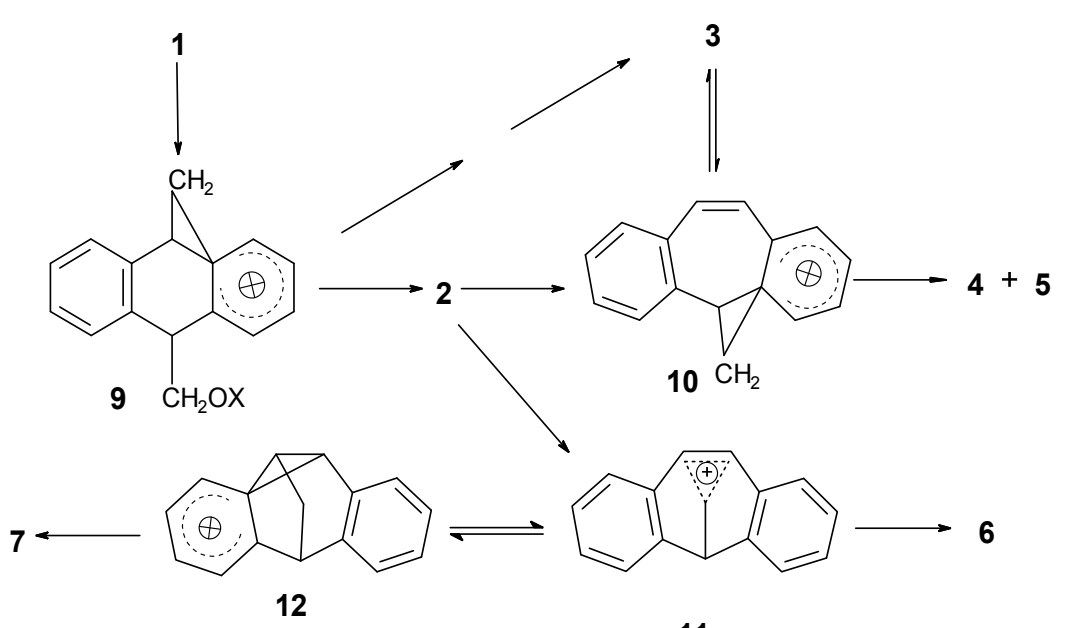


The ditosylate 1 may give, by ionization via the phenonium route, the intermediate ion 9 which may lead to $\mathbf{2}$ by proton elimination. The ion $\mathbf{9}$ may also be stabilized by reaction with solvent giving the corresponding cycloheptene ester, which, by a second ionization and reaction with solvent, gives compound 3. This compound may be formed also from the intermediate 10 by double solvent reaction. From the ion 10, by reaction with solvent, results compound $\mathbf{4}$, and the de-protonation yields compound 5. By an elimination reaction from compound $\mathbf{2}$, the hydrocarbon $\mathbf{8}$ is obtained.

The compound $\mathbf{2}$ may be transformed, by ionization via the $\pi$ route, in the intermediate $\mathbf{1 1}$. This nonclassical ion ${ }^{16}$ may react with solvent, giving compound $\mathbf{6}$ or it rearranges, by the phenonium route leading to compound 7 , after reaction with solvent.

The products and their percentages depend on the solvolytic conditions (acid solvent, buffered or unbuffered reaction medium, reaction temperature, etc.). The conditions favoring the longer life of the intermediates generate more rearranged products. Beside the previous intermediates 10-12, a number of benzylic ions may be considered. The endo/exo ratio $(4.5 / 2)$ of products $6(X=H)^{12,14}$ endorses as intermediates the ion $\mathbf{1 2}$ and not an open benzylic ion.

In all the performed solvolyses the phenonium route represents the main route and only in few cases (Table 1 entries 3-5) small quantities of the $\pi$ route products 6 and 7 were identified. ${ }^{12,14}$ According to the authors the products with dibenzocyclooctane skeleton are the kinetically controlled products, while those with dibenzocycloheptane skeleton are those formed in thermodynamic conditions.

A rearrangement dibenzoC8 $\leftrightarrow$ dibenzoC7 was evidenced also by Cava et $a .^{17}$ during the transformation of the 1,2,5,6-dibenzocyclooctadiene tetrabromide (13). By the solvolysis of this compound with methanol, ethanol or buffered acetic acid, two dibenzocycloheptane derivatives have been obtained, namely the acetals $14\left(\mathrm{R}=\mathrm{CH}_{3}\right.$ or $\left.\mathrm{C}_{2} \mathrm{H}_{5}\right)$ and the hydrocarbon 15 , resulting by a degradation reaction (see Figure 2).

The stereochemistry of the compounds with a dibenzo[a.d]cycloheptene skeleton substituted in position 5 is of interest. The saddle shape of cycloheptariene ring, with a butterfly movement is pointed out by literature. ${ }^{18-21}$ The 5 -substituted compounds may have two conformations with the substituent in a pseudo-axial and/or pseudoequatorial position. For example, the ${ }^{1} \mathrm{H}-\mathrm{NMR}$ investigation of compound $\mathbf{1 6}$ showed a main conformer 16b (see Figure 3) with the $\mathrm{CH}_{3}$ in pseudo-axial position and $\mathrm{OH}$ in pseudoequatorial position. ${ }^{19}$ The study of $5 H-5 R$ compounds shows as major isomer the one with $\mathrm{R}$ in a pseudo-axial position. ${ }^{20,21}$ This is most probably due to the steric interaction of the substituent with the neighboring aromatic hydrogen atoms. ${ }^{19,21}$

Despite the nearby position of the double bond and the ionization center in the main conformer $\mathbf{2 b}$, the phenonium route is the favored transformation, with cycle enlargement. This is most probably due to the lower nucleophilicity of the double bond.

The bridged products and their interconnection have been studied also recently. A rearrangement of compounds with dibenzobicyclo[2.2.2] octane skeleton to dibenzobicyclo[3.2.1] octane was first observed in the buffered acetolysis of tosylate 7 $(\mathrm{X}=\mathrm{Ts})^{22,23}$ which yielded a mixture of exo and endo acetates of alcohol $\mathbf{6}$. The importance of the stereochemistry of these compounds was evidenced by the preferential formation of $\mathbf{6}$ $(\mathrm{X}=\mathrm{Ac})$ exo in the buffered solvolysis of $7(\mathrm{X}=\mathrm{Ts})$, results explained considering a phenonium ion $\mathbf{1 2}$ as intermediate, and not an open benzylic ion. ${ }^{24,25}$

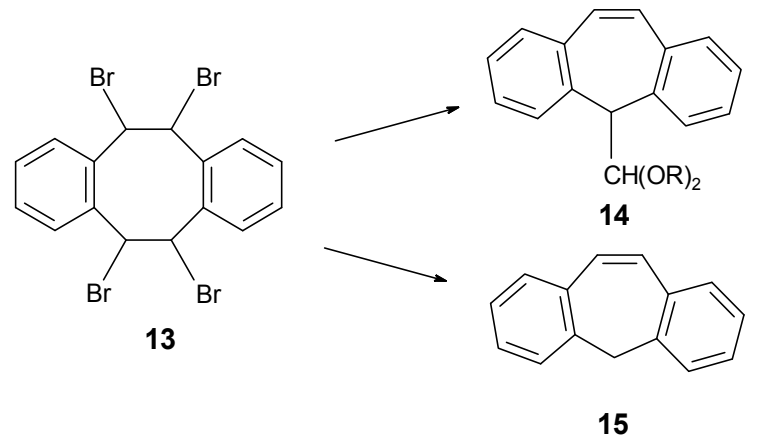

Fig. 2 - Transformation of the bromide $\mathbf{1 3}$ by solvolytic reactions. 


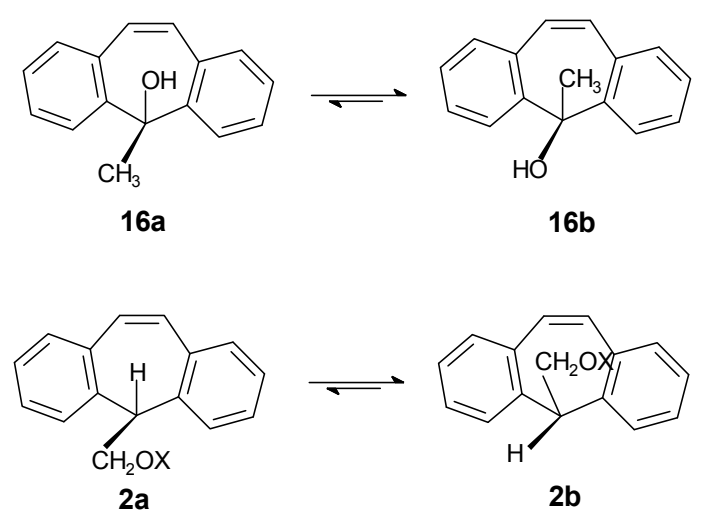

Fig. 3 - Conformational stability for compounds with dibenzo[a,d]cycloheptene skeleton.

This conclusion is reinforced by Pool et al., ${ }^{26}$ which, based on X-ray studies and molecular orbital calculation on type 7 structures (where $\left.\mathrm{X}=\mathrm{COCH}_{3}, \quad \mathrm{COCCl}_{3}, \quad \mathrm{SO}_{2} \mathrm{CH}_{3}, \quad \mathrm{COC}_{6} \mathrm{H}_{5}\right)$, demonstrate the intervention of the phenonium ion intermediate in their heterolysis.

In order to render the $\pi$ route more favorable, the compounds 2 have been modified by substituting the double bond with a group enhancing its nucleophilicity. Thus, the tosylate $\mathbf{1 7}(\mathrm{X}=\mathrm{Ts})$ has been synthesized and subjected to buffered and unbuffered solvolyses (see Figure 4). ${ }^{27,28}$

The main product obtained by buffered acetolysis was the hydrocarbon $18 \quad(75 \%)$ generated by double bond assistance ( $\pi$ route). It is a stable compound, even in unbuffered conditions representing $53 \%$ of the reaction mixture. ${ }^{27,28}$ This compound results most probably by a $\pi$ route, followed by $\mathrm{CH}_{3}$ de-protonation. The increase in the double bond nucleophilicity is accompanied also by the movement of the double bond towards the ionization center due to the steric hindrance between the $\mathrm{CH}_{3}$ group and the neighboring aromatic hydrogens. ${ }^{28}$ The acetate $\mathbf{1 7}$ obtained in around $10 \%$ yield in both types of solvolysis may be formed by direct reaction with the solvent or by a retro $\pi$ route.

In unbuffered conditions besides 18, the rearranged products $19(18 \%)$ and $20(4 \%)$ were isolated and characterized. These are obtained via phenonium and benzylic ions as intermediates. It is worth mentioning that in these solvolyses no product with dibenzocyclooctane skeleton was identified. ${ }^{27,29}$

The rearrangement of compounds such as $\mathbf{1 8}$ to compounds with dibenzobicyclo[2.2.2] cyclooctane skeleton was achieved by treating the alcohol $\mathbf{2 1}$ with trifluoroacetic acid. The reaction was performed at room temperature and was followed by ${ }^{1} \mathrm{H}-\mathrm{NMR}$ spectroscopy. According to the experimental results the following transformations were observed (see Scheme 3). ${ }^{29}$

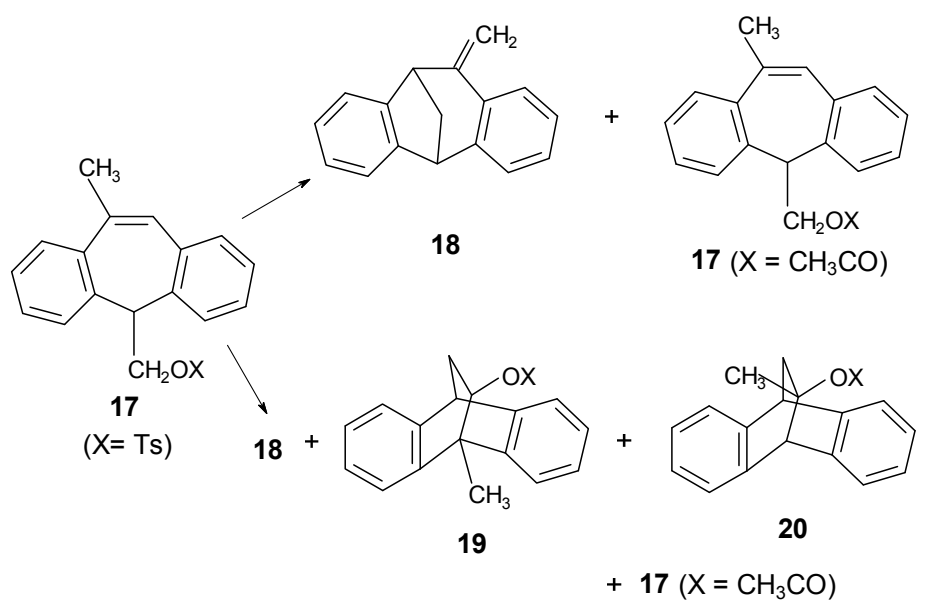

Fig. 4 - The products of buffered and unbuffered acetolysis of tosylate $\mathbf{1 7 .}$ 


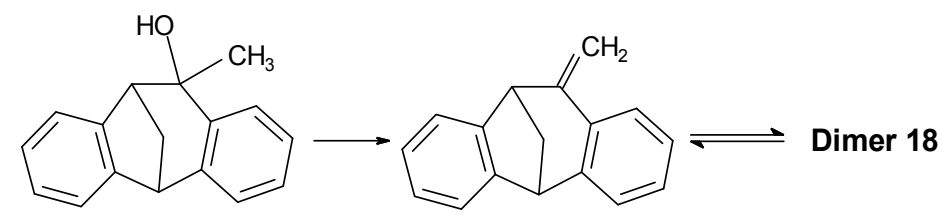

21

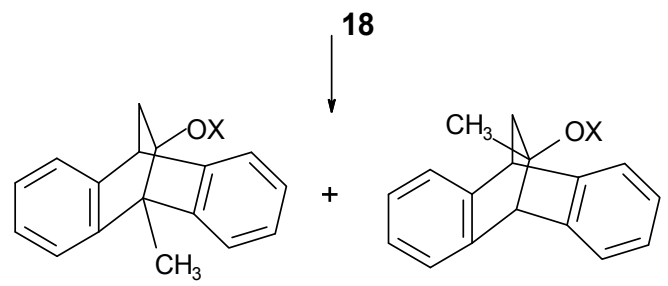

19

$\left(\mathrm{X}=\mathrm{CF}_{3} \mathrm{CO}\right)$

20

Scheme 3

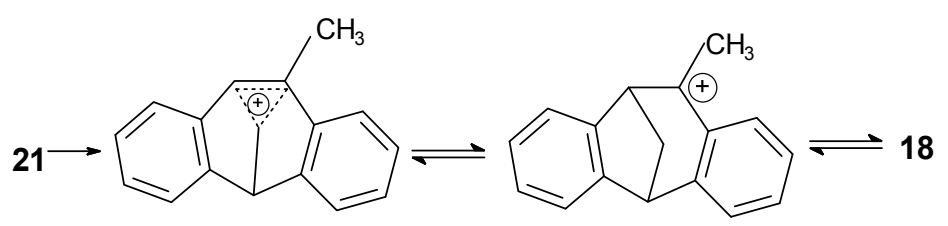

22

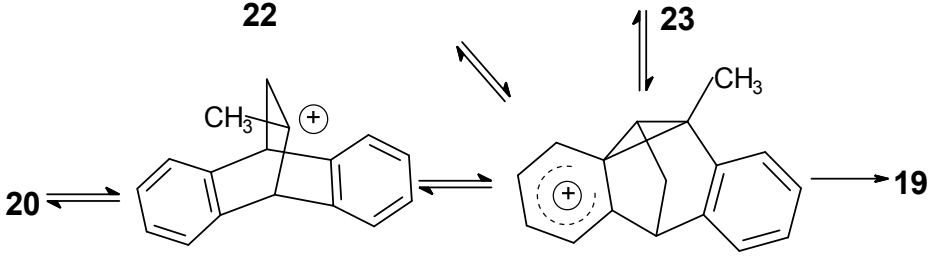

25

24

Scheme 4

After $5 \mathrm{~min}$. the hydrocarbon $\mathbf{1 8}$ was formed which may be protonated and rearranged to a mixture of compounds 19 and $20\left(\mathrm{X}=\mathrm{CF}_{3} \mathrm{CO}\right)$. After 15 min. the ratio $\mathbf{1 9 / 2 0}$ was $2.9 / 4$ while in three hours the main product was 19 (ratio $\mathbf{1 9} / \mathbf{2 0}=7 / 1.3) .^{28,29}$ This proves that derivative 19, with the substituent in the bridgehead position, is the thermodynamically stable product. The dimer of 18 decreased from $14.5 \%$ after $15 \mathrm{~min}$. to $8 \%$ after 3 hours. The transformation of $21(X=H)$, in these reaction conditions, into a mixture of trifluoroacetates 19 and $20 \quad\left(\mathrm{X}=\mathrm{CF}_{3} \mathrm{CO}\right)$ reconfirmed the rearrangement of compounds with dibenzobicyclo[3.2.1]octane skeleton into compounds with dibenzobicyclo[2.2.2]octane skeleton. As intermediates in these transformations we may consider the cations 22-25 (see Scheme 4).

The fact that compounds with dibenzobicyclo[2.2.2]octane skeleton are the thermodynamic products was underlined in a recent paper. $^{30}$ The author emphasized the synthetic value of the rearrangement of compounds with dibenzobicyclo[3.2.1] octane skeleton to dibenzobicyclo[2.2.2] octane derivatives, such reaction being used for synthesizing a variety of dual-cavity basket structures. By such rearrangements a number of molecules have been obtained, which may be used to identify drugs, to prepare new materials, as components of chemosensors or supramolecular catalysts. ${ }^{30}$

No rearrangement to dibenzoC7 compounds by retro $\pi$ route or to dibenzoC 8 products obtained by ring enlargement was observed in the solvolyses of methyl double bond substituted tosylate $17 .^{26}$

Interesting information regarding the dibenzoC8 compounds is also obtained from the pyrolysis of hydrocarbons 26-28. ${ }^{31}$ Inter-conversion of these hydrocarbons was experimentally proved, suggesting as intermediates radicals similar to the ions involved in the previously described solvolyses. During the pyrolysis, part of dibenzocyclooctatetraene (26) and dibenzosemibullvalene (27) rearranged to more stable compounds like dibenzobarrelene (28) (see Figure 5). By pyrolysis, this last compound turns into anthracene through retro-diene reaction. 
<smiles>C1=Cc2ccccc2C=Cc2ccccc21</smiles>

26<smiles>c1ccc2c(c1)C1CC2c2ccccc21</smiles>

27

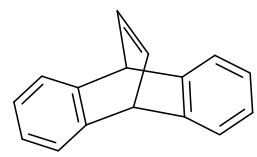

28

Fig. 5 - Structure of pyrolysed dibenzoC8 hydrocarbons.

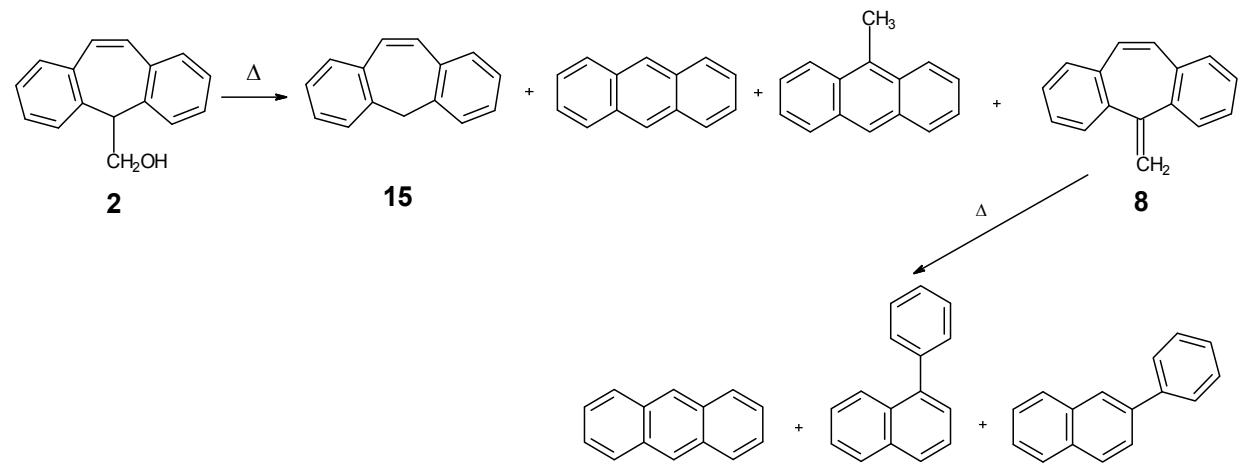

Scheme 5

The inter-conversion of the C8 skeleton was validated by Ciganek and coworkers. ${ }^{32}$ By photochemical reaction, dibenzobarellene turns into dibenzosemibullvalene. Such a conversion was also evidenced for the polycyclic biscorrannulenobarrelene dicarboxylate, having a central bicyclo[2.2.2] octane skeleton, transformed, by irradiation with a sun lamp, into the corresponding semibullvalene compound. ${ }^{33}$

The inter-conversion of these compounds represents an important tool for the preparation of new complex structures.

The pyrolysis behavior of other dibenzoC8 compounds depends on their chemical structure. The products obtained from alcohol $\mathbf{2}$ are the hydrocarbon 15, the degradation products anthracene and methyl anthracene and a small quantity of $\mathbf{8}^{34}$ In turn the hydrocarbon $\mathbf{8}$ gives by pyrolysis products with loss of two carbon atoms (Scheme 5). ${ }^{35}$

The transformations are explained by a diradical fragmentation of the cycloheptene ring. ${ }^{34,35}$

\section{Rearrangements of dibenzo-C9 compounds}

To reveal the importance of the steric factor in the choice between the phenonium and the $\pi$ route, compounds with two carbons in position 5 were synthesized and solvolyzed. The products of the buffered and unbuffered acetolyses resulted by the $\pi$ route due to the proximity of the double bond of the central ring to the reaction center. Thus, the nucleophilic assistance of the double bond is prevalent in this case.

Depending on the presence or not of the sodium acetate buffer, bicyclic products with two or three carbon atoms bridge were isolated (see Figure 6). ${ }^{36-38}$ The products and their percentage in the reaction mixture are presented in Table 2 .

The buffered acetolysis leads, by the $\pi$ route, to the two carbon bridge compounds: the acetates 30 $(\mathrm{X}=\mathrm{Ac})$ exo and endo in a molar ratio $1 / 2.4$. The hydrocarbons $\mathbf{3 2}$ and $\mathbf{3 3}$ were found in small quantities together with the compound with unchanged skeleton. The main products of the unbuffered acetolysis are the $\pi$ route hydrocarbon 33 and the rearranged acetate $\mathbf{3 1}(\mathrm{X}=\mathrm{Ac})$ beside a quantity of the acetate with unchanged skeleton (29, $\mathrm{X}=\mathrm{OAc}){ }^{36-38}$

In both types of solvolyses the $\pi$ route products are prevalent. According to the results from the unbuffered acetolysis of tosylate $\mathbf{3 1}(\mathrm{X}=\mathrm{Ts}),{ }^{36}$ the two carbon bridged compounds $\mathbf{3 0}$ exo/endo are the kinetically controlled products while the three 
carbon atom bridged compounds $\mathbf{3 1}$ and $\mathbf{3 2}$ are the thermodynamically stable ones. The transformation of $31(\mathrm{X}=\mathrm{Ts})$ to compound $29(\mathrm{X}=\mathrm{OAc})$ shows most probably a retro $\pi$ route mechanism.

By changing the leaving group of the compound 29, the composition of the product mixture changed (see Table 2). The content of the $\pi$ route products decrease in the following order: bromide $>$ tosylate $>$ amine. In the last case only $20 \%$ of compounds $\mathbf{3 0}$ exo and endo $(\mathrm{X}=\mathrm{Ac})$ composed the reaction mixture, the main product being the compound 29, with unchanged skeleton. ${ }^{39}$

For the bromide $29(\mathrm{X}=\mathrm{Br})$ even the buffered acetolysis gave a mixture rich in the rearranged compounds 31 and 32. Such result may be explained by a longer life of the intermediates which rearrange toward the thermodynamically stable products having a three carbon bridge $(\mathbf{3 1}, \mathbf{3 2}){ }^{37,39}$

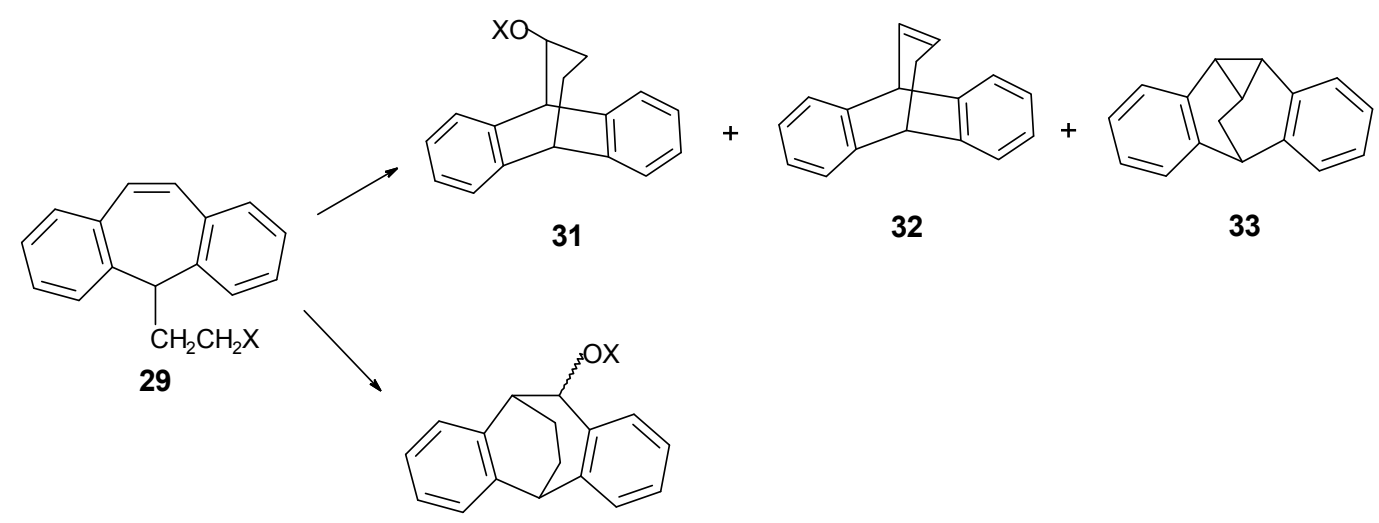

30

Fig. 6 - Products obtained by the solvolyses of tosylate $29(\mathrm{X}=\mathrm{OTs})$.

Table 2

Solvolytic transformation of compounds $\mathbf{2 9}$ and $\mathbf{3 1}$

\begin{tabular}{|c|c|c|c|c|c|c|c|c|c|}
\hline \multirow[t]{2}{*}{ No } & \multirow{2}{*}{$\begin{array}{l}\text { Initial } \\
\text { compd. }\end{array}$} & \multirow{2}{*}{$\begin{array}{l}\text { Reaction conditions } \\
\text { (molar ratio: } \\
\text { buffer/initial compd.) }\end{array}$} & \multicolumn{7}{|c|}{ Products $(\%)$} \\
\hline & & & 30 exo & 30 endo & 31 & 32 & 33 & 29 & Lit \\
\hline 1 & $29(\mathrm{X}=\mathrm{OTs})$ & a) $\mathrm{AcOH}$; b) $\mathrm{LiAlH}_{4}$ & $1.0(\mathrm{X}=\mathrm{H})$ & $1.0(\mathrm{X}=\mathrm{H})$ & $56(\mathrm{X}=\mathrm{H})$ & 7.5 & 21 & $13.5(\mathrm{X}=\mathrm{OH})$ & $\begin{array}{l}36- \\
38\end{array}$ \\
\hline 2 & $29(\mathrm{X}=\mathrm{OTs})$ & $\begin{array}{l}\text { a) } \mathrm{AcOH}+\mathrm{AcONa} \\
(1.5 / 1) ; \text { b) } \mathrm{LiAlH}_{4}\end{array}$ & $23.5(\mathrm{X}=\mathrm{H})$ & $58(\mathrm{X}=\mathrm{H})$ & $3.5(\mathrm{X}=\mathrm{H})$ & 3.5 & 1 & $10,5(\mathrm{X}=\mathrm{OH})$ & $\begin{array}{l}36- \\
38\end{array}$ \\
\hline 3 & $29(\mathrm{X}=\mathrm{Br})$ & a) $\mathrm{AcOH}$; b) $\mathrm{Na}_{2} \mathrm{CO}_{3}$ & \multicolumn{2}{|c|}{ traces } & $69(\mathrm{X}=\mathrm{H})$ & 10.7 & 19.7 & traces & 39 \\
\hline 4 & $29(\mathrm{X}=\mathrm{Br})$ & $\begin{array}{l}\text { a) } \mathrm{AcOH}+\mathrm{AcONa} \\
\text { (1.7/1); b) } \mathrm{Na}_{2} \mathrm{CO}_{3}\end{array}$ & \multicolumn{2}{|c|}{$39.5(X=H)$} & $48(\mathrm{X}=\mathrm{H})$ & 5.0 & 6.5 & $1.0(\mathrm{X}=\mathrm{OH})$ & 39 \\
\hline 5 & $31(\mathrm{X}=\mathrm{Ts})$ & a) $\mathrm{AcOH}$; b) $\mathrm{LiAlH}_{4}$ & $6.0(\mathrm{X}=\mathrm{H})$ & $1.0(\mathrm{X}=\mathrm{H})$ & $75.5(\mathrm{X}=\mathrm{H})$ & 1.0 & 3.5 & $9.0(\mathrm{X}=\mathrm{OH})$ & 36 \\
\hline 6 & $31(\mathrm{X}=\mathrm{Ts})$ & $\begin{array}{l}\text { a) } \mathrm{AcOH}+\mathrm{AcONa} \\
(1.5 / 1) ; b) \mathrm{LiAlH}_{4}\end{array}$ & $27.5(\mathrm{X}=\mathrm{H})$ & $56.5(\mathrm{X}=\mathrm{H})$ & $16 \mathrm{X}=\mathrm{H})$ & - & - & - & 36 \\
\hline
\end{tabular}

${ }^{*} \mathrm{Ac}=\mathrm{CH}_{3} \mathrm{CO}$<smiles>C1=CC2c3ccccc3C1c1ccccc12</smiles>

34<smiles>c1ccc2c(c1)CC1CCC2c2ccccc21</smiles>

36

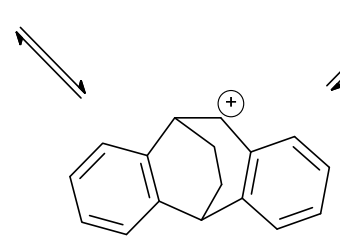


The hydrocarbon 32 confirms the formation, as intermediate, of the bridged non classical ion $\mathbf{3 4}$ (see Scheme 6). Besides, this assertion is confirmed by the higher content in compound $\mathbf{3 0}$ endo, proving a nucleophilic attack on the opposite site of the bridge (see Table 2). The initial formation of ion $\mathbf{3 4}$ seems more probable than that of the benzylic ion $\mathbf{3 5}$. This last ion seems an intermediate path to the rearranged three carbon bridge products obtained, most probably, from a phenonium ion $36 .{ }^{39}$ Such an ion was recently confirmed as intermediate in other reactions occurring in acid media. ${ }^{40}$
More information about the double bond assistance in the solvolysis of dibenzoC9 compounds was obtained by substituting the central double bond. Thus, tosylates $37(\mathrm{X}=\mathrm{Ts})$, with methyl (a) or phenyl (b) substituent at the double bond have been synthesized and solvolyzed in various conditions. ${ }^{28,}{ }^{41}$ The structure of the products depends on the reaction conditions and the type of substituent.

The results are presented in Table 3 .

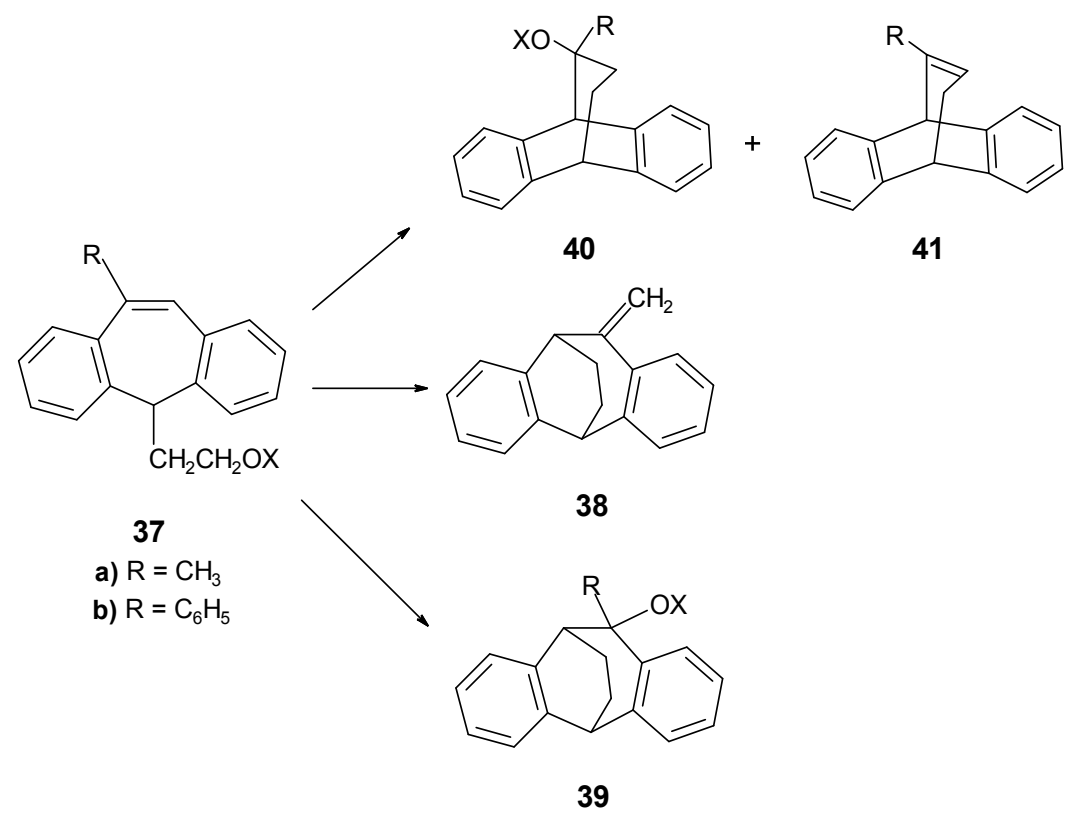

Fig. 7 - Products obtained by the solvolyses of tosylates $37 \mathbf{a}, \mathbf{b}$.

Table 3

The compounds obtained by solvolysis of tosylates $\mathbf{3 7}$ and alcohols $\mathbf{3 9}$

\begin{tabular}{|c|c|c|c|c|c|c|c|c|c|c|}
\hline \multirow[b]{2}{*}{ No } & \multirow{2}{*}{$\begin{array}{l}\text { Initial } \\
\text { compd. }\end{array}$} & \multirow{2}{*}{$\begin{array}{l}\text { React. conditions } \\
\text { (molar ratio: buffer } \\
\text { /initial compd.) }\end{array}$} & \multicolumn{8}{|c|}{ Products (\%) } \\
\hline & & & 38 & 42 & $\begin{array}{l}39 \\
\text { exo }\end{array}$ & $\begin{array}{c}39 \\
\text { endo }\end{array}$ & 40 & 41 & 37 & Lit \\
\hline 1 & 37a $(\mathrm{X}=\mathrm{Ts})$ & $\begin{array}{l}\mathrm{AcOH}+\mathrm{AcONa} \\
(1.5 / 1)\end{array}$ & 87.5 & - & - & - & - & $\begin{array}{l}5.0 \\
41 \mathrm{a}\end{array}$ & $\begin{array}{c}1.5 \\
37 \mathbf{a}(\mathrm{X}=\mathrm{Ac})\end{array}$ & $\begin{array}{c}28, \\
41\end{array}$ \\
\hline 2 & 37a $(\mathrm{X}=\mathrm{Ts})$ & $\mathrm{AcOH}$ & - & - & - & - & - & $\begin{array}{r}96.0 \\
41 \mathrm{a}\end{array}$ & $\begin{array}{c}3.0 \\
37 \mathbf{a}(X=A c)\end{array}$ & $\begin{array}{l}28, \\
41\end{array}$ \\
\hline 3 & 37a $(X=T s)$ & $\begin{array}{l}\text { aq. acetone }+\mathrm{CaCO}_{3} \\
(1.4 / 1)\end{array}$ & - & - & $\begin{array}{c}48.0 \\
\text { 39a }(X=H)\end{array}$ & $\begin{array}{c}48.0 \\
\text { 39a }(\mathrm{X}=\mathrm{H})\end{array}$ & - & - & $\begin{array}{c}1.5 \\
\mathbf{3 7} \mathbf{a}(\mathrm{X}=\mathrm{H})\end{array}$ & $\begin{array}{l}28, \\
41\end{array}$ \\
\hline 4 & $37 \mathbf{b}(\mathrm{X}=\mathrm{Ts})$ & $\begin{array}{l}\mathrm{AcOH}+\mathrm{AcONa} \\
(1.5 / 1)\end{array}$ & - & - & - & - & - & $\begin{array}{l}81.5 \\
\mathbf{4 1 b}\end{array}$ & $\begin{array}{c}8.0 \\
\mathbf{3 7 b}(\mathrm{X}=\mathrm{Ac})\end{array}$ & $\begin{array}{l}28, \\
41\end{array}$ \\
\hline 5 & $37 \mathbf{b}(\mathrm{X}=\mathrm{Ts})$ & $\mathrm{AcOH}$ & - & - & - & - & - & $\begin{array}{l}69.5 \\
41 \mathrm{~b}\end{array}$ & $\begin{array}{c}27.5 \\
\text { 37b }(X=A c)\end{array}$ & $\begin{array}{l}28, \\
41\end{array}$ \\
\hline 6 & $37 \mathbf{b}(\mathrm{X}=\mathrm{Ts})$ & $\begin{array}{l}\text { aq. acetone }+\mathrm{CaCO}_{3} \\
(1.4 / 1)\end{array}$ & - & - & $\begin{array}{c}20.0 \\
\text { 39b }(\mathrm{X}=\mathrm{H})\end{array}$ & $\begin{array}{c}20.5 \\
\text { 39b }(X=H)\end{array}$ & - & - & $\begin{array}{c}46.5 \\
\mathbf{3 7 b}(\mathrm{X}=\mathrm{H})\end{array}$ & $\begin{array}{r}28, \\
41\end{array}$ \\
\hline 7 & 39a $(\mathrm{X}=\mathrm{H})$ & $\mathrm{Ac}_{\mathrm{f}} \mathrm{OH}(0.08 \mathrm{~h})$ & 98 & - & - & - & - & - & - & 29 \\
\hline 8 & 39a $(\mathrm{X}=\mathrm{H})$ & $\mathrm{Ac}_{\mathrm{f}} \mathrm{OH}(24 \mathrm{~h})$ & 1.5 & 34.0 & - & - & $\begin{array}{c}10.5 \\
\text { 40a }\left(\mathrm{X}=\mathrm{Ac}_{\mathrm{f}}\right)\end{array}$ & $\begin{array}{l}54.0 \\
41 \mathrm{a}\end{array}$ & - & 29 \\
\hline
\end{tabular}

${ }^{*} \mathrm{Ac}=\mathrm{CH}_{3} \mathrm{CO} ; \mathrm{Ac}_{\mathrm{f}}=\mathrm{CF}_{3} \mathrm{CO}$ 


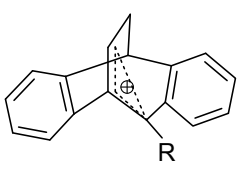

43

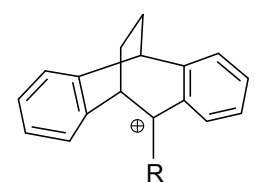

44

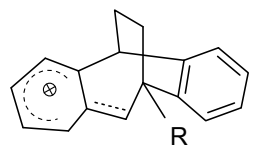

45

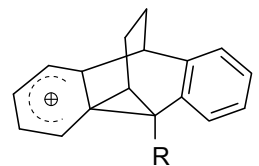

46

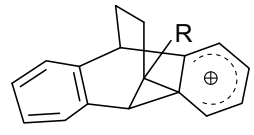

47

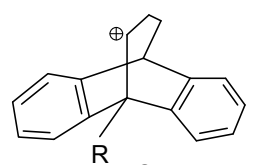

48

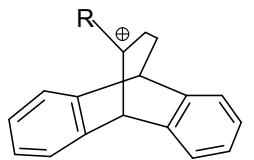

49

Fig. 8 - Possible intermediates in the solvolyses of tosylates $\mathbf{3 7 a}, \mathbf{b}$.

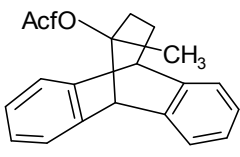

$40 a$

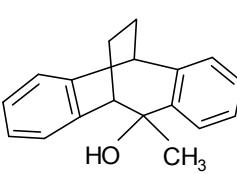

$39 a$

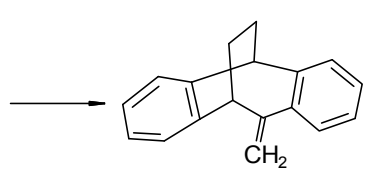

38

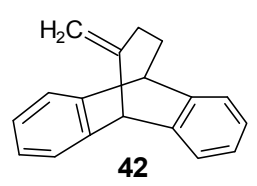

Scheme 7

The main product in the buffered acetolysis of tosylate 37a was hydrocarbon 38. The methyl group enhanced the nucleophilicity of the double bond, the $\pi$-route product being obtained in higher quantity than in the case of the unsubstituted tosylate $(87.5 \% \quad$ vs. $81.5 \%)$. The unbuffered acetolysis gave the rearranged three carbons bridge product having the substituent connected only to the bridge. ${ }^{28,41}$

The phenyl substituted compound showed a different behavior, giving in both buffered and unbuffered acetolysis, as main product, the rearranged hydrocarbon $41 \mathrm{~b}\left(\mathrm{R}=\mathrm{C}_{6} \mathrm{H}_{5}\right)$. For this tosylate, more acetate with unchanged skeleton was obtained compared to the methyl substituted tosylate. In unbuffered conditions the content of acetate with structure $\mathbf{3 7 b}$ was higher than in buffered conditions $(27.5 \%$ vs. $8.0 \%)$ which may indicate a retro $\pi$ route due to a possible reionization process (see Table 3 , entries 4,5 ). ${ }^{41}$
The reaction products suggest a number of intermediate ions 43-49 possibly involved in these transformations (See Figure 8).

The bicyclic two carbons bridge alcohols 39a $(\mathrm{X}=\mathrm{H})$ and 39b $(\mathrm{X}=\mathrm{H})$ were obtained by the solvolysis of tosylates 37a,b in aq. acetone. ${ }^{28,41}$ The predominance of the $\pi$-route was also observed in the case of methyl substituted tosylate $\mathbf{3 7 a}$ where these products represent $96 \%$ of the reaction mixture. It is also important to mention that the ratio endo/exo is around 1, which supports an open benzylic ion intermediate $\mathbf{4 4}$ in this case, the ion stabilized by the presence of the substituent. The structures of non classical ion $\mathbf{4 3}$ generated by $\pi$ route as well as the classical phenonium ions $\mathbf{4 6}$ and $\mathbf{4 7}$ (see Figure 8) have been confirmed by recent publications. ${ }^{16,40}$ The fundamental and practical relevance of such intermediates in the synthesis of new drug or materials was underlined. ${ }^{40}$ 
The substituent $\mathrm{R}$ stabilized the benzylic ions leading to products like $\mathbf{3 8}$ or $\mathbf{3 9}$. By successive rearrangements, products with the substituent attached to the three carbon atoms bridge such as 40 and 41 were obtained (see Figure 7). ${ }^{41}$

Similar rearrangements of two carbons bridge compounds were observed in the trifluoroacetolysis of alcohols 39a $(\mathrm{X}=\mathrm{H})$ (see Scheme 7) and 39b (X=H).

From the alcohol 39a $\left(\mathrm{R}=\mathrm{CH}_{3}\right)$ the first product on treatment with trifluoroacetic acid was hydrocarbon 38 (see Scheme 7). After a longer reaction time this compound rearranged to three carbons bridge products $40 \mathrm{a}, 41 \mathrm{a}$ and 42 . As for the acetolysis of tosylate $\mathbf{3 7 a}$ (see Table 3), no compound with the substituent in the bridgehead position was obtained. The alcohol 39b $\left(\mathrm{R}=\mathrm{C}_{6} \mathrm{H}_{5}\right)$ gave as only product the hydrocarbon $\mathbf{4 1 b}$ $\left(\mathrm{R}=\mathrm{C}_{6} \mathrm{H}_{5}\right) .{ }^{29}$

Contrary to the dibenzoC8 compounds, the rearrangement of the two carbons bridged compounds led only to bridge substituted compounds in both cases $\left(\mathrm{R}=\mathrm{CH}_{3}\right.$ or $\left.\mathrm{C}_{6} \mathrm{H}_{5}\right)$. The thermodynamically stable bridgehead substituted product from the dibenzoC8 series was not identified in the dibenzoC9 case.

The different stability of the bridged substituted products for the dibenzoC 8 and dibenzoC 9 may be explained by steric reasons. The shorter bridge of two carbon atoms leads to the deviation of the substituent from the plane determined by the marked hydrogen atoms of the two phenyl rings (see Figure 9). The steric hindrance in compounds with a bridge of three carbon atoms where the marked hydrogens and $\mathrm{R}$ are in the same plane destabilizes the bridgehead substituted compounds and only products with a substituted bridge are obtained.
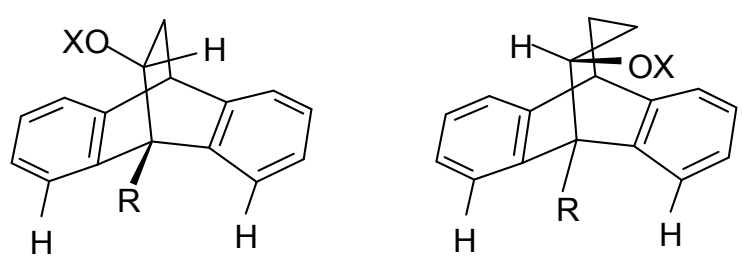

Fig. 9 - Structures of the bridgehead substituted compounds with dibenzobicyclo[2,2,2] and dibenzobicyclo[3.2.2] skeletons.

Differences in the case of dibenzoC9 compounds, compared to the results for dibenzoC8, appeared also in the thermal rearrangement. The pyrolyses of hydrocarbons $\mathbf{3 2}$ and $\mathbf{3 3}$ (see Figure 6) lead to different products than the solvolyses. The compounds 55, $\mathbf{5 6}$ and $\mathbf{5 7}$ are the final products. ${ }^{42}$ The transformations may be explained by the following rearrangements (see Scheme 8):

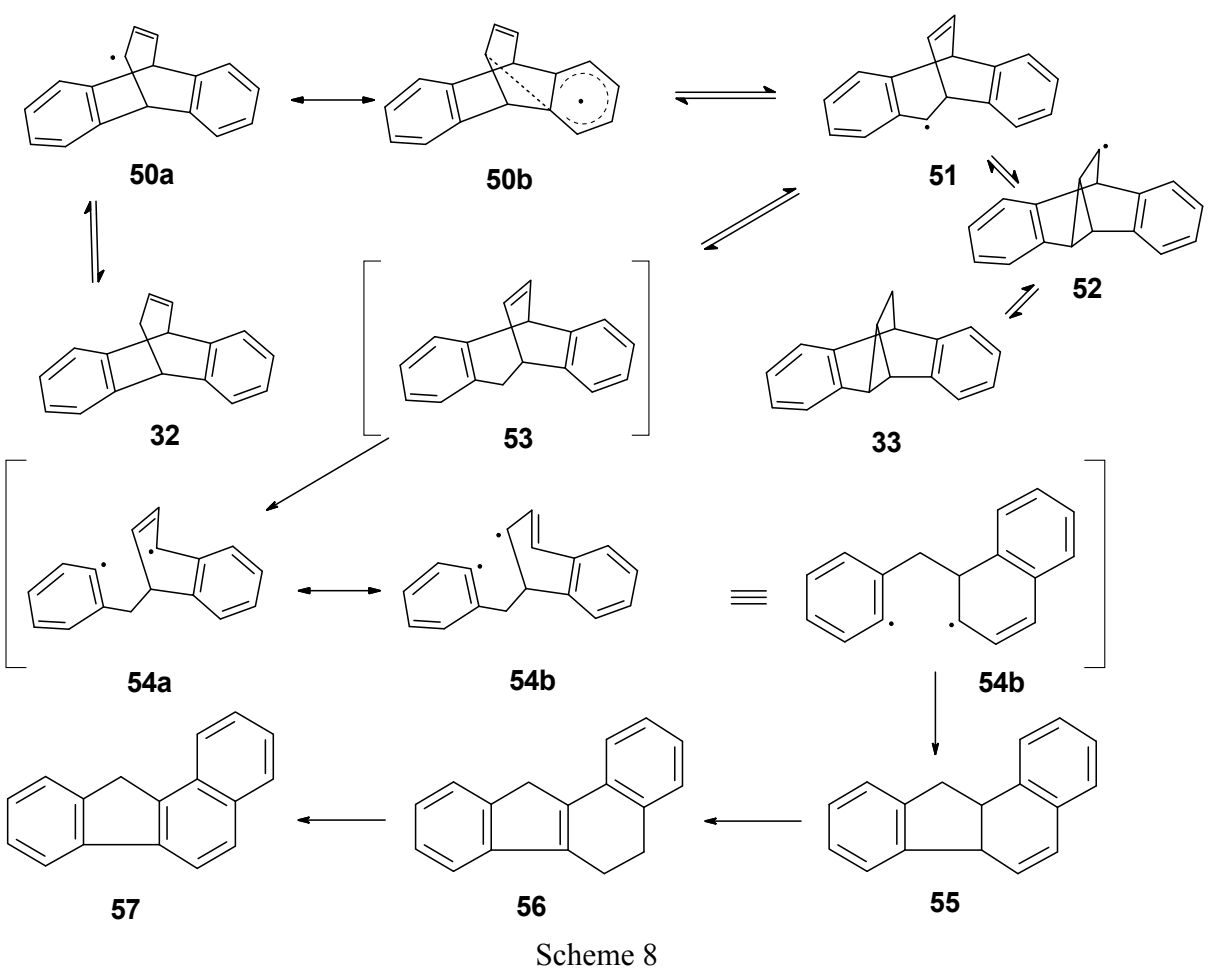


The presence of three aromatic rings in the final compound $\mathbf{5 7}$ explains its high stability.

Other dibenzoC9 derivatives behaved like the previously presented hydrocarbon $\mathbf{3 2}$.

The final products from the pyrolysis of compounds $30(\mathrm{X}=\mathrm{Ac})$ exo and endo or $\mathbf{3 1}(\mathrm{X}=\mathrm{Ac})$ are the polyaromatic hydrocarbons 55-57. ${ }^{43-45}$

Beside the synthetic aspects, the performed studies focused also on the kinetic behavior of these compounds.

The kinetics of the solvolyses was followed by titration of the resulted toluenesulphonic acid in time. A good first order is usually displayed in the studied acetolyses. ${ }^{46-48}$ For the tosylate 29 ( $\mathrm{X}=\mathrm{OTs}$ ), the ratio of the acetate with the same skeleton $v s$ the $\pi$ route products varies proportionally with the buffer concentration. ${ }^{36-38} \mathrm{~A}$ careful analysis of the formation of the acetate with the same skeleton as the tosylate suggest two reaction paths, namely a nucleophilic substitution and a retro $\pi$ route. ${ }^{46,47}$

A similar behavior was noticed in the solvolyses of tosylate $\mathbf{5 8}$ with the same skeleton as 29, having substituents $\left(\mathrm{X}=\mathrm{Cl}, \mathrm{CH}_{3}\right.$ and $\left.\mathrm{OCH}_{3}\right)$ on one of the aromatic rings. ${ }^{48}$

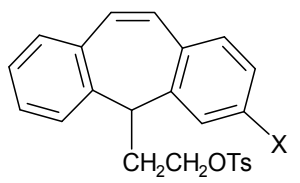

58

For the pyrolyses, the kinetics was followed by gas chromatography. It gave a clear picture concerning the stability of the discussed compounds.

It is important to mention that some of the solvolysis products were raw materials for complex heterocyclic compounds, with biological activity, such as: pyrylium or pyridine tryptycene analogues or pyrimidines and pyrazoles with dibenzo-barellene or dibenzo-homobarellene skeletons, like $\mathbf{5 9}$ and $\mathbf{6 0}$, respectively. ${ }^{49-52}$

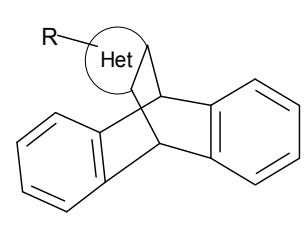

59

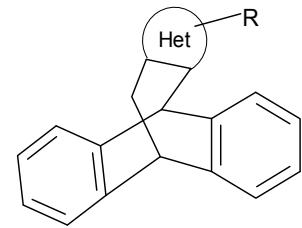

60
Het $=$ pyrylium Het $=$ pyrylium
Het $=$ pyridinium Het $=$ pyridinilu
Het $=$ pyrazole
$\mathrm{R}=\mathrm{C}_{6} \mathrm{H}_{5}, \ldots$

\section{CONCLUSIONS}

The rearrangements of dibenzo $\mathrm{C} 8$ and dibenzo C9 compounds are an important tool for the synthesis of complex polycyclic compounds with potential biological activity.

The stereochemistry of the molecule directs the transformation of the studied compounds by the phenonium- or the $\pi$-route respectively.

Methyl substitution of the central ring double bond enhances the formation of the $\pi$-route compounds.

The variation of the solvent nucleophilicity generates different types of products, the desired products being obtained by the right choice of reaction conditions.

The reaction mechanism involves classical and non-classical ions depending on the substrate structure and the reaction conditions. The proposed intermediates are confirmed by the stereochemistry of the products.

Last but not least it is important to mention that a research performed many years ago with less effective tools is still viable today, this being confirmed by recently published results of other research groups.

\section{REFERENCES}

1. F. López-Muñoz and C. Alamo, Curr. Pharm. Design, 2009, 15, 1563-1586. https://doi.org/10.2174/ 138161209788168001

2. R. S. Aronstam, Life Sci., 1981, 28, 59-64. https://doi.org/10.1016/0024-3205(81)90366-0

3. S. Merkaš, M. Litvić, I. Cepanec and V. Vinković, Molecules, 2005, 10, 1429-1437. https://doi.org/10.3390 /10121429

4. C. Böhler, D. Stein, N. Donati and H. Grützmacher, New J. Chem., 2002, 26, 1291-1295. http://doi.org/ 10.1039/b203670c

5. M. V. Rudorfer and W. Z. Potter, Cell. Mol. Neurobiol., 1999 , 19 , 373-409. https://doi.org/10.1023/A:1006949816036

6. M. Q. Zhang, A. van de Stolpe, O. P. Zuiderveld and H. Timmerman, Eur. J. Med. Chem., 1997, 32, 95-102. https://doi.org/10.1016/S0223-5234(97)87535-6

7. R. Chockalingam, B. M. Gott and C. R. Conway, in "Antidepressants. Handbook of Experimental Pharmacology", M. Macaluso and S. Preskorn (Eds), Springer, Cham, vol. 250, 2018, 37-48. https://doi.org/ 10.1007/164_2018_133

8. J. Schneider, M. Patterson and X. F. Jimenez, Cleve. Clin. J. Med., 2019, 86, 807-814. https://doi.org/10.3949/ ccjm.86a.19005

9. J. W. Black and S. B. Kalindjian, Pharmacol.Toxicol., 2002, 91, 275-281, https://doi.org/10.1034/j.16000773.2002.910602.x.

10. C. M. R. Low, I. M. Buck, T. Cooke, J. R. Cushnir, S. B. Kalindjian, A. Kotecha, M. J. Pether, N. P. Shankley, 
J. G. Vinter and L. Wright, J. Med. Chem., 2005, 48, 6790-6802. https://doi.org/10.1021/jm049069y

11. E. Cioranescu, A. Bucur, M. Banciu and C. D Nenitzescu, Rev. Roum. Chim., 1965, 10, 141-148; E. Cioranescu, A. Bucur, M. Elian and C. D. Nenitzescu, Rev. Roum. Chim., 1965, 10, 149-159.

12. E. Cioranescu, A. Bucur, F. Badea, M. Rentzea and C. D. Nenitzescu, Tetrahedron Lett. 1969, 10, 1867-1870. https://doi.org/10.1016/S0040-4039(01)88034-5

13. E. Cioranescu, A. Bucur, F. Badea, M. Banciu, M. Voicu and C. D. Nenitzescu, Tetrahedron Lett., 1964, 5, 38353839. https://doi.org/10.1016/S0040-4039(01)93302-7

14. A. Bucur, "Solvolytic rearrangements in dibenzocycloheptatriene and dibenzocyclooctatriene systems", PhD Thesis, 1969, Bucharest

15. E. Cioranescu, A. Bucur, M. Elian, M. Banciu, M. Voicu and C. D. Nenitzescu,. Rev. Roum. Chim., 1965, 10, 161-174.

16. R. Properzi, P. S. J. Kaib, M. Leutzsch, G. Pupo, R. Mitra, C. K. De, L. Song, P. R. Schreiner and B. List, Nature Chemistry, 2020, https//doi:10.1038/s41557-02000558-1.

17. M. P. Cava, R. Pohlke, B. W. Erickson, J. C. Rose and G. Fraenkel, Tetrahedron, 1962, 18, 1005-1011. https://doi.org/10.1016/S0040-4020(01)99263-4.

18. E. Cioranescu, A. Voicu and M. Elian, Rev. Roum. Chim., 1989, 34, 87-102.

19. M. Elian, Rev. Roum. Chim., 1990, 35, 281-297.

20. A. Hjelmencrantz, A. Friberg and U. Berg, J. Chem. Soc., Perkin Trans. 2, 2000, 1293-1300. https://doi.org/10.1039/B001410I

21. M. Elian, "Applications of NMR spectroscopy to dibenzocycloalkane systems", $P h D$ Thesis, 1973, Bucharest.

22. Gh. Mihai, "Syntheses and rearrangements in bicyclooctane and dibenzobicyclooctane systems", $P h D$ Thesis, 1971, Bucharest.

23. E. Cioranescu, A. Mihai, G. Mihai, M. Elian and C.D. Nenitzescu, Rev. Roum. Chim., 1965, 10, 175-183.

24. M. D. Stanescu, C. Florea, F. Chiraleu, A. Hirtopeanu and P. Sezonov, Rev. Roum. Chim., 1998, 43, 861-866.

25. M. D. Stanescu, C. Florea and V. Campeanu, Rev. Roum. Chim., 2002, 47, 303-307.

26. B. R. Pool, J. M. White and P. P. Wolynec, J. Org. Chem., 2000, 65, 7595-7601. https://doi.org/10.1021/ jo0055638.

27. M. Stanescu, M. Elian and E. Cioranescu, Rev. Roum. Chim., 1987, 32, 969-973.

28. M. D. Stanescu, "Solvolysis reactions in dibenzocycloalkene systems with substituted double bond", PhD Thesis, 1982, Bucharest.

29. M. Stanescu, M. Elian and E. Cioranescu, Rev. Roum. Chim., 1986, 31, 1001-1011.

30. T. Neal, W. Wang, L. Zhiquan, R. Peng, P. Soni, H. Xie and J. D. Badjić, Chem. Eur. J., 2019, 25, 1242-1248. https://doi.org/10.1002/chem.201805246.

31. M. Banciu, M. D. Stanescu, A. Petride, L. Parvulescu and M. Pop, Chem. Ber., 1993, 126, 2513-2517. https://doi.org/10.1002/cber.19931261127.
32. E. J. Ciganek, J. Am. Chem. Soc., 1966, 88, 2882-2883. https://doi.org/10.1021/ja00964a068.

33. A. Sygula, R. Sygula and P. W. Rabideau, Tetrahedron Lett., 2005, 46, 1189-1192. https://doi.org/10.1016/ j.tetlet.2004.12.053.

34. M. D. Banciu, A. Popescu, L. Parvulescu, C. Costea, C. Draghici, C. Ciuculescu and D. Mihaiescu, ARKIVOC, 2002, (ii), 19-29. https://doi.org/10.3998/ ark.5550190.0003.203.

35. M. D. Banciu, C. Costea, C. Draghici, A. Banciu, D. Mihaiescu and D. Ciuculescu, J. Anal. Appl. Pyrolysis 2003, 67, 359-368. https://doi.org/10.1016/S01652370(02)00074-8.

36. E. Cioranescu, M. Banciu, R. Jelescu, M. Rentzea, M. Elian and C. D. Nenitzescu, Tetrahedron Lett., 1969, 10(23), 1871-1874, https://doi.org/10.1016/S00404039(01)88035-7.

37. E. Cioranescu, M. Banciu, R. Jelescu, M. Rentzea, M. Elian and C. D. Nenitzescu, Rev. Roum. Chim., 1969, 14, 911-927.

38. M. D. Banciu, "Solvolytic reactions of dibenzocycloalkane derivatives", PhD Thesis, 1968, Bucharest.

39. M. Banciu, F. Badea, R. Jelescu and E. Cioranescu, Rev. Roum. Chim., 1975, 20, 121-127.

40. F. Arico, A. Maranzana, M. Musolino and P. Tundo, Pure Appl. Chem., 2018, 90, 93-107 https://doi.org/10.1515/pac-2017-0604; S. Xu, H. M. Holst, S. B. McGuire, and N. J. Race, J. Am. Chem. Soc., 2020, 142, 8090-8096. https://dx.doi.org/10.1021/ jacs.0c02095.

41. M. Stanescu, G. Mihai, L. Stanescu and E. Cioranescu, Rev. Roum. Chim., 1979, 24, 197-207.

42. M. Banciu, M. D. Stanescu, C. Florea, A. Petride, C. Drăghici and E. Ciorănescu, Bull. Soc. Chim. Fr. 1991, 128, 919-925.

43. M. Banciu, M. D. Stanescu, C. Florea, A. Petride, and E. Ciorănescu, Rev. Roum. Chim., 1992, 37, 1211-1217.

44. M. Banciu, C. Florea, A. Petride, M. D. Stanescu and E. Ciorănescu, Rev. Roum. Chim., 1993, 38, 271-276.

45. C. Florea, "Polycyclic compounds with physiologic activity", $P h D$ Thesis, 1995, Bucharest.

46. M. Voicu and F. Badea, Rev. Roum. Chim., 1969, 14, 929-939.

47. M. Voicu, "Kinetic studies in solvolysis reactions. Acetolysis reactions with $\pi$ assistance", PhD Thesis, 1971, Bucharest.

48. M. Voicu, F. Badea and A. Voicu, Rev. Roum. Chim., 1973, 18, 131-144.

49. M. Stanescu, M. Banciu and A. T. Balaban, Rev. Roum. Chim., 1989, 34, 617-622.

50. M. D. Banciu, M. D. Stanescu and F. Chiraleu, Rev. Roum. Chim., 1989, 34, 1921-1930.

51. M. D. Stanescu, M. D. Banciu and F. Chiraleu, Rev. Roum. Chim., 1991, 36, 119-125.

52. M. D. Banciu, C. Hada and M. D. Stanescu, Rev. Roum. Chim., 1991, 36, 671-681. 
